\title{
PERSEPSI AKUNTAN PUBLIK TERHADAP AKUNTABILITAS KEUANGAN PARTAI POLITIK PADA KANTOR AKUNTAN PUBLIK DI MALANG
}

\author{
Ike Rachmawati \\ PT Golden Leave Jaya Abadi, JI Raya Madyopuro No.25-33 Malang \\ Email: Ikerachmawati86@gmail.com/No Telepon:085649698028
}

\begin{abstract}
This study entitled "Perceptions of Political Parties and Financial Accountability Campaign Funds by Public Accountant" with the aim of the research to find out if there were no differences in the perception of public accounting and financial accountability of political party campaign funds. Data collection methods used in this study is to use surveys in which sample collection through questionnaires. Researchers took the object of research in public accounting firm located in the city of Malang, a sample number of 33 respondents. The analysis used in this research is descriptive analysis with the help of the computer program SPSS (Statistical Package For Social Science) version 11. Sampling techniques are used to using the method judgemen / purposive sampling, the researcher uses a specific consideration of the elements are selected as the sample population. Tests are conducted to answer the researchers' hypothesis using one sample t test trials. The first hypothesis testing results show that the sig. (2tailed) $<0.05$ then $\mathrm{H} 1$ is received and $\mathrm{Ho}$ is rejected, this shows that the hypothesis is accepted which means the researchers found no differences in the perception of public accountants of the financial accountability of political parties, while the second hypothesis test results showed the sig. (2-tailed) $<0.05$ then the $\mathrm{H} 1$ accepted and rejected $\mathrm{Ho}$ ang means there is no difference in the perception of public accountants to the accountability of campaign funds. The conclusion from this study that there is no difference in perception of the public accountant and financial accountability of political party campaign funds. Suggestions are given for further research investigator of the study population are expected not only to the public accounting firm in the city of Malang, but is extended to the public accounting firm on the outskirts of Malang and increase the number of variables with the variable political party financial reports and financial statements of a political party after the audit so that the bias comparison between the results of audit visits to the perception of public accountants.
\end{abstract}

Kaywords: Perceptions, Accountability, Political Parties

\section{PENDAHULUAN}

Karakter dasar partai politik adalah meraih kekuasaan atas nama rakyat, yang dilakukan melalui pemilu. Bila menang partai politik akan memegang kekuasaan melalui jalur pengambil keputusan (eksekutif) dan jalur pembuat kebijaksanaan (legislatif). Setiap keputusan yang dibuat oleh partai politik melalui kedua jalur tersebut selalu mengatasnamakan rakyat, dan berimplikasi luas terhadap kehidupan rakyat. Oleh karena itu partai politik seharusnya memastikan bahwa setiap tindakan yang dilakukan demi rakyat yang diwakilinya, bebas dari pengaruh politik uang dan pengaruh kelompok kepentingan. Namun pada kenyataannya, sulit sekali melepaskan partai politik dari pengaruh kelompok 
kepentingan karena kehidupan partai politik justru tergantung pada sumbangan yang diterimanya.

Terkait dengan semakin membudayanya korupsi di berbagai departemen di negara ini pemerintah mulai proaktif dalam menjalankan sistem pemerintahannya salah satunya dalam bidang politik. Sejak awal persiapan pemilihan umum, merajalelanya politik uang sudah disadari akan menganggu keabsahan hasil pemilu. Oleh karena itu, para perancang paket undang-undang politik memasang sejumlah.rambu-rambu aturan untuk mencegah dan mengawasi terjadinya politik uang serta menjatuhkan sanksi bagi partai politik yang terbukti melakukannya. Salah satunya adalah kewajiban partai-partai politik untuk menyerahkan catatan keuangannya guna diaudit oleh kantor akuntan publik, sebelum pelaksanaan pemungutan suara serta sesudahnya. Aturan ini diharapkan dapat mendorong transparansi keuangan partai politik sehingga meminimalkan praktek-praktek politik uang.

Kantor-kantor akuntan publik yang diminta oleh Komisi Pemilihan Umum nyaris menyerah untuk melakukan audit, meskipun mereka sudah mengembangkan audit khusus bagi partai politik. Hampir semua partai politik, termasuk yang besar, tidak memiliki catatan keuangan yang lengkap, hingga akhirnya diputuskan hanya memeriksa pembukuan dewan pimpinan pusat. Namun, itupun tidak bisa diserahkan oleh semua partai. Selain itu, minimnya data yang tersedia, menyebabkan kantor-kantor akuntan publik yang dikoordinasikan oleh Ikatan Akuntan Indonesia ini tidak memberikan opini terhadap hasil auditnya, sebagaimana yang biasanya mereka lakukan.

\section{Rumuan Masalah}

Berdasarkan latar belakang di atas, maka permasalahan yang akan diteliti oleh peneliti adalah apakah tidak terdapat perbedaan persepsi Akuntan Publik terhadap akuntabilitas keuangan partai politik yang berada di Kota Malang?

\section{Batasan Masalah}

Untuk lebih mengarahkan pembahasan selanjutnya, maka penulis membatasi permasalahan sebagai berikut:

1. Tidak terdapat perbedaan persepsi akuntan publik terhadap akuntabilitas keuangan partai politik yang berada di Kota Malang.

2. Tidak terdapat perbedaan persepsi akuntan publik terhadap akuntabilitas keuangan dana kampanye partai politik. 


\section{Tujuan dan Manfaat Penelitian}

\section{Tujuan Penelitian}

1. Apakah tidak terdapat perbedaan persepsi akuntan publik terhadap akuntabilitas keuangan partai politik yang berada di Kota Malang.

2. Apakah tidak terdapat perbedaan persepsi akuntan publik terhadap akuntabilitas keuangan dana kampanye partai politik berada di Kota Malang.

\section{Manfaat Penelitian}

1. Penelitian ini di harapkan dapat menambah wawasan dan pengetahuan peneliti pada masalah yang di kaji, yaitu mengenai persepsi Akuntan Publik terhadap akuntabilitas laporan keuangan partai politik yang berada di kota Malang.

2. Sebagai sarana dalam menerapkan teori-teori yang sudah di peroleh di bangku perkuliahan terutama dalam hal mengidentifikasi masalah, menganalisa situasi dan mengadakan penelitian formal.

3. Hasil penelitian ini di harapkan dapat bermanfaat bagi akuntan publik dalam melaksanakan pemeriksaan terhadap laporan keuangan partai politik.

4. Hasil penelitian ini di harapkan dapat memperkaya konsep atau teori yang mendukung perkembangan ilmu pengetahuan akuntansi sektor publik, khususnya yang terkait dengan akuntabilitas keuangan partai politik.

\section{Metodologi Penelitian \\ Jenis Penelitian}

Berdasarkan jenisnya, penelitian ini dapat dikategorikan sebagai penelitian opini (Opinion Research). Menurut Indriantoro dan Supomo (2002:29) penelitian opini merupakan penelitian terhadap fakta berupa opini atau pendapat orang atau responden. Berdasarkan karakteristiknya penelitian ini termasuk ke dalam penelitian diskripstif. Menurut Indriantoro dan Supomo (2002:17) penelitian diskriptif adalah penelitian yang bertujuan untuk melakukan pengukuran yang cermat dan sistematis terhadap peristiwa tertentu dengan cara menafsirkan data yang telah ada atau mendiskripsikan fakta yang terjadi.

\section{Lokasi Penelitian}

Penelitian ini dilakukan di Kantor Akuntan Publik di wilayah kota Malang. Pertimbangan utamanya adalah untuk mengetahui persepsi Akuntan Publik atas akuntabilitas keuangan partai politik yang berada di Malang. 


\section{Populasi dan Sampel}

\section{Populasi}

Menurut Sugiyono (2008:80) populasi (population) adalah wilayah generalisasi yang terdiri atas obyek/subyek yang mempunyai kualitas dan karakteristik tertentu yang di tetapkan oleh peneliti untuk dipelajari dan kemudian ditarik kesimpulannya. Populasi dalam penelitian ini adalah :

Tabel 1

Populasi Penclitian

\begin{tabular}{|c|c|c|}
\hline No. & $\begin{array}{l}\text { Nama } \\
\text { Kantor Nkuntan Publik }\end{array}$ & Kantor Alsuntan Publik \\
\hline 1. & Drs. Suprihadi dan Rekan & J1. Bunga Andong Selatan Kav. 26 Malang \\
\hline 2. & Drs. Nasikin dan Kekan & J1. Semeru 11 lj (lantas 2) Malang \\
\hline 4. & $\begin{array}{l}\text { Made Sudarma, Ihomas dan } \\
\text { Dewi }\end{array}$ & 11. Dorowats 8 Malang \\
\hline 5 & Timny Tundi of Partmer & T1 Karya Timur $31 \mathrm{~A}$ Malang \\
\hline 6. & $\begin{array}{l}\text { Duti, Barntidrig, Sudirriadji } \& \\
\text { Dadang }\end{array}$ & I1. Tapakduru no, 15 Malang \\
\hline 7. & Drs. Jimmy Andreanus & I. Retawu no. 26. Malang \\
\hline 8. & $\begin{array}{l}\text { Kanto. Drs. Toni. Frans dan } \\
\text { Darmawan }\end{array}$ & J1. Majapahit no. 1/D Malang \\
\hline 9. & Dwi Kora Haripriyanto & J1. Pahlawan 229 A Baic Arjosari \\
\hline 10. & Subagyu \& Iuthif & J1. Jemuler al Basuki Ralmiad No. 6 D 1Malan \\
\hline
\end{tabular}

\section{Sampel}

Menurut Sugiyono (2008:81) sampel (sample) adalah bagian dari jumlah dan karateristik yang dimiliki oleh populasi tersebut. Sampel yang diambil dari populasi harus betul-betul representatif (mewakili) Jadi, sampel adalah subkelompok atau sebagian dari populasi. Dengan mempelajari sampel, peneliti akan mampu menarik kesimpulan yang dapat digeneralisasikan terhadap populasi penelitian.

Teknik penentuan sampel yang digunakan dalam penelitian ini adalah dengan non probability sampling. Menurut Sugiyono (2008:84) non probability sampling adalah teknik pengambilan sample yang tidak memberi peluang/kesempatan sama bagi setiap unsure atau anggota populasi untuk dipilih sebagai sample.Teknik ini berupa purposive sampling yaitu teknik pemilihan sampel berdasarkan kriteria atau pertimbangan tertentu, dengan syarat :

1. Sampel adalah akuntan publik yang berada di kota Malang

2. Sampel adalah akuntan publik yang pernah melakukan audit terhadap laporan keuangan partai politik. 
Tabel 2

Sampel Penelitian

\begin{tabular}{|c|l|l|}
\hline No. & \multicolumn{1}{|c|}{ Nama KAP } & \multicolumn{1}{c|}{ Alamat KAP } \\
\hline 1. & Drs. Suprihadi dan Rekan & $\begin{array}{l}\text { J1. Bunga Andong Selatan Kav. 26 } \\
\text { Malang }\end{array}$ \\
\hline 2. & Drs. Nasikin dan Rekan & J1. Semeru 11-15 (lantai 2) Malang \\
\hline 3. & Drs. Jimmy Andreanus & J1. Retawu no. 26 Malang \\
\hline 4. & Made Sudarma, Thomas dan Dewi & I1. Dorowati 8 Malang \\
\hline 5. & Jimmy Budi \& Partner & I1. Karya Timur 31A \\
\hline 6. & Doli, Bambang, Sudarmadji \& Dadang & I1. Tapakdoro no. 15 Malang \\
\hline 7. & Drs. Kanto, Tony, Frans \& Darmawan & I1. Majapahit 1 D Malang 65141 \\
\hline
\end{tabular}

Sumber: Directori Kantor Akuntan Publik Cabang

\section{Jenis dan Sumber Data \\ Jenis Data}

Jenis data yang digunakan dalam penelitian ini adalah data kualitatif (berupa pendapat responden yang diperoleh dengan menyebarkan kuesioner) yang di kuantitatifkan menggunakan skala likert agar dapat di proses dalam statistik.

\section{Sumber Data}

Data primer penelitian ini adalah data yang diperoleh dari objek dan sampel penelitian dengan survey lapangan berkaitan dengan persepsi Akuntan Publik terhadap akuntabilitas keuangan partai politik di kota Malang melalui pengisian kuisioner.

\section{Metode Pengumpulan Data}

Metode yang digunakan untuk memperoleh data dalam penelitian ini adalah metode survey.Sedangkan tehnik yang digunakan adalah dengan menggunakan pertanyaan tertulis melalui kuesioner. Tipe pertanyaan dalam kuesioner ini adalah tertutup.

\section{Oprasionalisasi variabel}

Dalam penelitian ini menggunakan variabel-variabel sebagai berikut:

\section{Akuntabilitas Keuangan Partai Politik}

Dalam Bastian (2007:156) menjelaskan bahwa "Pertanggungjawaban keuangan organisasi partai politik, sebagai suatu entitas yang menggunakan dana publik yang besar, harus transparan sehingga pertanggungjawaban keuangan merupakan hal yang tidak dapat ditawar lagi". Pernyataan yang di ajukan menggunakan skala likert untuk mengetahui akuntabilitas keuangan partai politik pada penelitian ini adalah: 
1. Sumber keuangan partai politik berasal dari iuran anggota, sumbangan yang sah menurut hukum, bantuan keuangan dari anggaran pendapatan dan belanja negara/ anggaran pendapatan dan belanja daerah.

2. Penggunaan keuangan partai politik melalui pernyataan mengenai bukti-bukti transaksi yang mendukung, ketepatan dalam pengalokasian dan organisasi, serta efisiensi penggunaan dana partai politik.

3. Bentuk pertanggungjawaban keuangan partai politik meliputi pencatatan dan pelaporan pembukuan partai politik.

\section{Akuntabilitas Laporan Dana Kampanye}

Bentuk pertanggungjawaban pengelolaan partai politik peserta pemilu adalah penyampaian laporan dana kampanye (semua peserta pemilu), serta laporan keuangan (khusus partai politik), yang harus di audit oleh akuntan publik, ke KPU serta terbuka untuk di akses publik.Item pernyataan mengenai akuntabilitas laporan dana kampanye meliputi adanya rekening khusus dana kampanye partai politik serta pelaporan keuangan dana kampanye kepada KPU.

\section{Metode Analisa Data dan Uji Hipotesis}

Analisa data adalah cara atau langkah - langkah untuk mengolah data primer maupun data sekunder, yang bermanfaat bagi peneliti untuk mencapai tujuan akhir penelitian. Analisa data dilakukan dengan menggunakan bantuan program komputer yaitu SPSS (Statistical Package For Social Science) versi 11. Beberapa teknik analisa data yang digunakan dalam penelitian ini yaitu:

\section{Uji Validitas dan Uji Reliabilitas}

\section{Uji Validitas}

Pengujian validitas dilakukan dengan menggunakan analisis butir dengan product moment correlation. Untuk mengukur Validitas maka digunakan teknik korelasi produk dari Pearson :

$$
\begin{aligned}
r= & \frac{n \sum x_{i} y_{i}-\sum x_{i} y_{i}}{\left.\sqrt{\left\{n x_{i}^{2}\right.}-\left(\sum x\right)\right\}\left\{n \sum y_{i}^{2}-\left(\sum y_{1}\right)^{2}\right\}} \\
& \text { Keterangan : } \\
& r=\text { koefisien korelasi setiap item } \\
\mathrm{x} & =\text { nilai setiap item } \\
\mathrm{y} & =\text { nilai total semua item } \\
\mathrm{n} & =\text { banyaknya responden }
\end{aligned}
$$




\section{Uji Reliabilitas}

Uji reliabilitas dalam penelitian ini menggunakan progam SPSS 11 for windows. Uji reliabilitas di maksudkan untuk menunjukkan tentang sifat suatu alat ukur apakah cukup akurat, stabil atau konsisten dalam mengukur apa yang diinginkan. Dengan ketentuan jika nilai Cronbach Alpha $\geq 0,60$, maka item pertanyaan di nyatakan reliable.

\section{Uji Hipotesis}

Pengujian hipotesis dalam penelitian ini menggunakan one sample $t_{\text {test. }}$ Menurut Santoso (2005:41) dalam melakukan analisis pada uji t syarat yang di berlakukan yaitu jika probabilitas $>0,05$ maka $\mathrm{H}_{0}$ diterima, jika probabilitas $<0,05$ maka $\mathrm{H}_{0}$ di tolak.

\section{Hasil Penelitian Dan Pembahasan}

\section{Gambaran Umum Responden}

Data dalam penelitian ini diperoleh dengan menyebar kuesioner kepada Kantor Akuntan Publik yang berada di wilayah kota Malang dan yang pernah melakukan audit terhadap laporan keuangan partai politik.. Hasil penyebaran dan penerimaan kuesioner dapat di lihat pada tabel berikut :

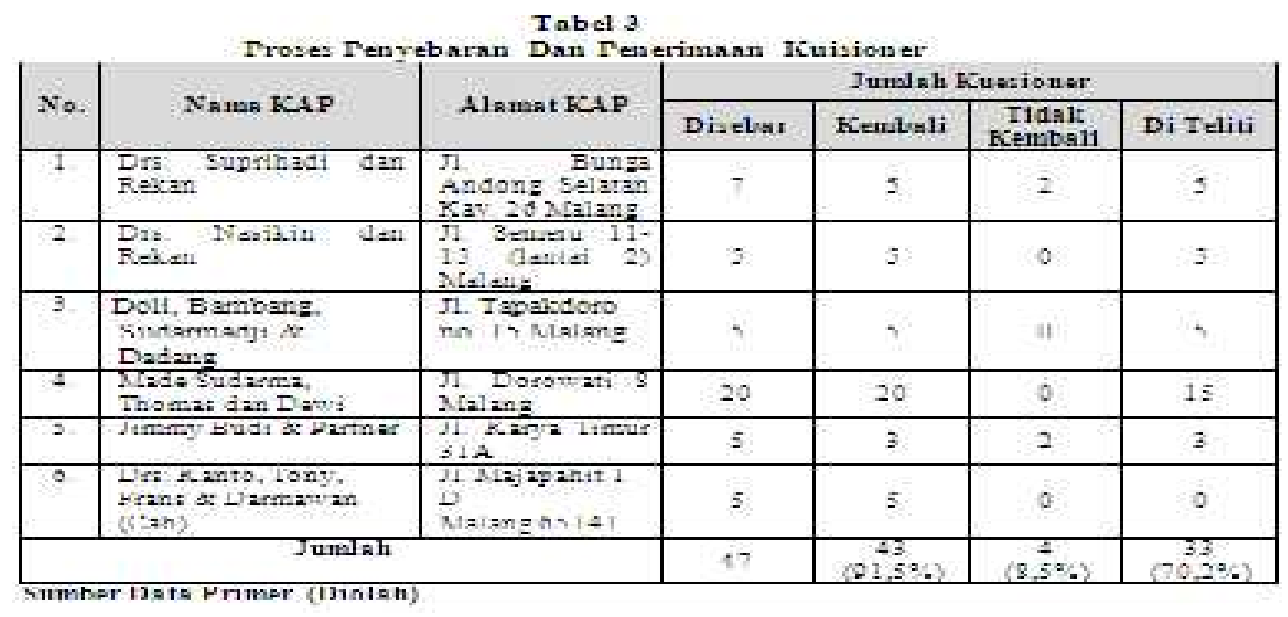

Tabel 3 menunjukkan bahwa jumlah kuesioner yang disebar sebanyak 47 kuesioner sedangkan jumlah kuesioner yang kembali sebanyak 43 (91,5\%) kuesioner dan jumlah kuesioner yang tidak kembali sebanyak 4 (8,5\%) kuesioner. Dari total kuesioner yang kembali yang memenuhi syarat untuk bisa di teliti sebanyak $33(70,2 \%)$ kuesioner, hal ini disebabkan 10 kuesioner tidak terisi dengan sempurna. 


\section{Diskriptif Statistik.}

Analisis yang digunakan untuk menguji diskriptif statistik pada penelitian ini menggunakan program komputer yaitu SPSS versi 11 for windows dengan prosedur frequencies. Tujuan uji diskriptif adalah untuk mengetahui tentang penyebaran jawaban responden dari kuesioner berdasarkan item-item pernyataan dalam penelitian ini.

\section{Akuntabilitas Keuangan Partai Politik}

Akuntabilitas keuangan partai politik terdiri dari tiga poin penting. Poin pertama yaitu sumber keuangan partai politik yang terdiri dari iuran anggota, sumbangan, dan bantuan dari Anggaran Pendapatan Belanja Negara/Daerah. Poin kedua adalah mengenai penggunaan keuangan partai politik yang terdiri dari bukti-bukti, alokasi, dan efisiensi. Sedangkan poin ketiga adalah mengenai pertanggungjawaban keuangan partai politik yang terdiri dari pencatatannya dan pelaporannya.

\section{Sumber Keuangan Partai Politik}

Berikut di sajikan mengenai persepsi akuntan publik terhadap akuntabilitas keuangan partai politik di tinjau dari segi sumber keuangan partai politik yang terdiri dari iuran anggota, sumbangan, dan bantuan dari Anggaran Pendapatan Belanja Negara/Daerah.

\section{luran Anggota}

Tabel 4

Persepat Mengenai Iuran Auggota

\begin{tabular}{|c|c|c|c|c|c|c|c|c|c|c|c|}
\hline \multirow{2}{*}{ Peruyatasu } & \multicolumn{2}{|c|}{$3 \pi 5$} & \multicolumn{2}{|r|}{ Is } & \multicolumn{2}{|r|}{$\mathbf{N}$} & \multicolumn{2}{|r|}{5} & \multicolumn{2}{|c|}{55} & \multirow{2}{*}{ Tots] } \\
\hline & $\mathrm{N}$ & 60 & 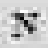 & 90 & $\mathbf{y}$ & $\mathrm{Cb}$ & $x$ & 60 & $\mathrm{~N}$ & 80 & \\
\hline PI 1 & 10 & $205=$ & - & - & 1 & $30 \%$ & $\Xi$ & $152 \%$ & 17 & $515 \mathrm{~s}$ & 38 \\
\hline$P 12$ & 13 & $39 \div 2=$ & $\div$ & $121^{1 \%}$ & \pm & $121 \%$ & 12 & $36+\%$ & - &. & $\exists 3$ \\
\hline Iot: & 23 & 348 & $\div$ & $619=$ & 5 & $76^{3}=$ & 17 & $256 \%$ & 17 & $256 \%$ & 65 \\
\hline
\end{tabular}

Sumber Data Primer.(Diolah)

Keterangan :

P1.1: Tanggapan responden terhadap pernyataan bahwa keuangan partai bersumber dari iuran anggota.

P1.2: Tanggapan responden terhadap pernyataan bahwa keuangan partai yang bersumber dari iuran anggota telah cukup untuk memenuhi kebutuhan partai.

Tabel menunjukkan tanggapan responden terhadap sumber keuangan partai politik dari aspek iuran anggota. Sebagai ilustrasi tanggapan responden terhadap pernyataan 
keuangan partai politik bersumber dari iuran anggota (P1.1) yaitu 10 (30,3\%) responden menyatakan sangat tidak setuju, 1 (3\%) responden menyatakan netral, 5 (15,2\%) responden menyatakan setuju, dan 17 (51,5\%) responden menyatakan sangat setuju.

\section{Sumbangan}

Tabel 히

Persepsi Mengenai Sumbangan

\begin{tabular}{|c|c|c|c|c|c|c|c|c|c|c|c|}
\hline \multirow{3}{*}{ Pernya tasll } & \multirow{2}{*}{\multicolumn{2}{|c|}{ STS }} & \multirow{2}{*}{\multicolumn{2}{|c|}{ TS }} & \multirow{2}{*}{\multicolumn{2}{|c|}{$\mathrm{N}$}} & \multirow{2}{*}{\multicolumn{2}{|c|}{5}} & \multirow{2}{*}{\multicolumn{2}{|c|}{ SS }} & \multirow{3}{*}{ Totel } \\
\hline & & & & & & & & & & & \\
\hline & $\mathrm{N}$ & $\mathrm{BO}_{0}$ & $N$ & $a_{0}$ & $\mathrm{~N}$ & 90 & $\mathrm{~N}$ & 80 & $\mathrm{~N}$ & 90 & \\
\hline$P_{21}$ & 27 & $818^{2}=$ & - & - & - & - & 5 & $152^{\circ}=$ & 1 & $3.0 \%=$ & 33 \\
\hline$\$ 22$ & 14 & $424 \%$ & - & $z$ & 4 & $121 \%$ & 3 & $242 \%$ & 7 & $212 \%$ & 33 \\
\hline P23 & 19 & $57.6 \%$ & - & - & 4 & $121 \%$ & 5 & $182 \%$ & 4 & $121 \%$ & 33 \\
\hline$P_{24}$ & 24 & $72^{-2}=$ & - & - & - & - & 7 & $212^{\circ}=$ & 2 & $61 \%$ & 33 \\
\hline$D_{25}$ & 9 & $273 \%$ & 7 & $212^{\circ}=$ & 1 & $30 \%$ & 6 & $182 \%$ & 10 & $303 \%$ & 33 \\
\hline P2.6 & 20 & $60.6^{\circ} \%$ & 5 & $152 \%$ & - & + & 5 & $152^{\circ} \mathrm{s}$ & 3 & $9.1 \%$ & 33 \\
\hline$P_{2} 7$ & 13 & $39.4 \%$ & 9 & $273 \%$ & 2 & $61 \%$ & 5 & $152 \%$ & 4 & $121 \%=$ & 33 \\
\hline$\$ 2.8$ & 25 & $-58 \%$ & 1 & $30 \%$ & & $0.0 \%$ & 3 & $91 \%$ & 4 & $121 \%$ & 33 \\
\hline P29 & 21 & $63.6^{a}=$ & 3 & $9.1 \%$ & - & - & 5 & $152^{\circ} \mathrm{s}$ & 4 & $121^{\circ}=$ & 33 \\
\hline$P_{2} .10$ & 23 & $69-9 \%$ & - & - & I & $30 \%$ & 5 & $152^{\circ}=$ & 4 & $121^{\%}=$ & 33 \\
\hline$P_{211}$ & 22 & $6679=$ & - & - & 5 & $152 \%$ & 4 & $121 \%$ & 2 & $6.1 \%$ & 33 \\
\hline Iotal & 212 & $6424^{2}=$ & 30 & $788^{2} \%$ & 19 & $576 \%$ & 59 & $1788 \%$ & 43 & $1303^{2} \%$ & 363 \\
\hline
\end{tabular}

Keterangan :

P2.1:Tanggapan responden terhadap pernyataan bahwa keuangan partai politik bersumber dari sumbangan

P2.2 :Tanggapan responden terhadap pernyataan bahwa keuangan partai politik dari sumbangan berupa uang

P2.3 :Tanggapan responden terhadap pernyataan bahwa partai politik menerima sumbangan berupa uang dari perorangan dengan mencantumkan identitas yang jelas

P2.4 :Tanggapan responden terhadap pernyataan bahwa partai politik menerima sumbangan berupa uang dari perorangan tidak melebihi batas yang ditetapkan Undang-Undang.

P2.5 :Tanggapan responden terhadap pernyataan bahwa partai politik menerima sumbangan berupa uang dari perusahaan/badan usaha dengan mencantumkan identitas yang jelas

P2.6:Tanggapan responden terhadap pernyataan bahwa partai politik menerima sumbangan berupa uang dari perusahaan/badan usaha tidak melebihi batas yang ditetapkan Undang-Undang.

P2.7:Tanggapan responden terhadap pernyataan bahwa keuangan partai politik bersumber dari sumbangan berupa barang

P2.8 :Tanggapan responden terhadap pernyataan bahwa partai politik menerima sumbangan berupa barang dari perorangan dengan mencantumkan identitas yang jelas

P2.9 :Tanggapan responden terhadap pernyataan bahwa partai politik menerima sumbangan berupa barang dari perorangan tidak melebihi batas yang ditetapkan Undang-Undang.

P2.10: Tanggapan responden terhadap pernyataan bahwa partai politik menerima sumbangan berupa barang dari perusahaan/badan usaha dengan mencantumkan identitas yang jelas

P2.11 : Tanggapan responden terhadap pernyataan bahwa partai politik menerima sumbangan berupa barang dari perusahaan/badan usaha tidak melebihi batas yang ditetapkan Undang-Undang. 
Iabel o

Persepsi Mengenai APBN APBD

\begin{tabular}{|c|c|c|c|c|c|c|c|c|c|c|c|}
\hline \multirow{2}{*}{ Peruyatay } & \multicolumn{2}{|c|}{ STS } & \multicolumn{2}{|r|}{ TS } & \multicolumn{2}{|c|}{$x$} & & \multicolumn{2}{|c|}{55} & \multirow{2}{*}{$\underset{\mathrm{N}}{\mathrm{Total}}$} \\
\hline & $\bar{N}$ & 96 & $\bar{N}$ & 60 & $\bar{S}$ & 96 & $\mathrm{~N}$ & 86 & $\bar{N}$ & 86 & \\
\hline q & 23 & $69,7 \%$ & - & . & - & 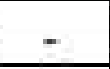 & 4 & $121 \%$ & 6 & $132^{\circ}=$ & - \\
\hline & 13 & $39.4 \%$ & 9 & $273 \%$ & 2 & $6.1 \%$ & 9 & $273 \%$ & $=$ & - & \\
\hline & 21 & $636 \%$ & 1 & $30 \%$ & - & - & -7 & $212 \%$ & 4 & $21 \%$ & \\
\hline & 29 & $379 \%$ & 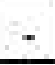 & . & - & $=$ & 4 & $121 \%$ & 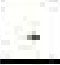 & $=$ & $\cdots$ \\
\hline Ional & 86 & $55,2 \%$ & 10 & $-5 \%$ & 2 & $1.5 \%$ & 24 & $132 \%$ & 10 & $7,6 \%$ & \\
\hline
\end{tabular}

Sumber Data Primer. (Diolah)

Keterangan

P3.1:Tanggapan responden terhadap pernyataan bahwa partai politik menerima bantuan dari pemerintah.

P3.2 :Tanggapan responden terhadap pernyataan bahwa bantuan dari pemerintah telah cukup untuk memenuhi kebutuhan partai.

P3.3 :Tanggapan responden terhadap pernyataan bahwa bantuan dari pemerintah telah digunakan untuk operasional kesekretariatan partai.

P3.4:Tanggapan responden terhadap pernyataan bahwa bantuan dari pemerintah telah cukup digunakan untuk pendidikan politik.

Tabel menunjukkan tanggapan responden terhadap sumber keuangan partai politik aspek bantuan dari Anggaran Pendapatan Belanja Negara/Daerah. Sebagai ilustrasi tanggapan responden terhadap pernyataan bahwa partai politik menerima bantuan dari pemerintah Yaitu $23(69,7 \%)$ responden menyatakan sangat tidak setuju, 4 (12,1\%) responden menyatakan setuju, dan $6(18,2 \%)$ responden menyatakan setuju.

\section{Penggunaan Keuangan Partai Politik}

Persepsi akuntan publik terhadap akuntabilitas keuangan partai politik di tinjau dari segi penggunaan keuangan partai politik terdiri dari aspek bukti-bukti, alokasi dan efisiensi.

\section{Bukti-Bukti}


I abel 7

Perzepii Mrengenai Bulati-BuIcti

\begin{tabular}{|c|c|c|c|c|c|c|c|c|c|c|c|}
\hline \multirow{2}{*}{ Peruy stan } & \multicolumn{2}{|c|}{575} & \multicolumn{2}{|r|}{75} & \multicolumn{2}{|c|}{$\mathrm{N}$} & \multicolumn{2}{|r|}{5} & \multicolumn{2}{|c|}{55} & \multirow{2}{*}{ Iota } \\
\hline & $\mathrm{N}$ & $8 \mathrm{a}$ & $x$ & 6 & $\mathbf{N}$ & 90 & $\mathrm{~N}$ & 96 & $\mathrm{~N}$ & $2 \mathrm{e}$ & \\
\hline$I \div 1$ & 25 & $7 \leq 30$ & - & - & - & - & 3 & $912=$ & $E$ & $1510=$ & 33 \\
\hline$I=1$ & 21 & $6 \pm 5=$ & - & - & I & $\exists 90$ & 3 & $91^{\circ}=$ & 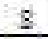 & $2 \pm 23=$ & 33 \\
\hline$I=5$ & 25 & $753=$ & - & - & 1 & 502 & 1 & $30=$ & 8 & $1323=$ & 33 \\
\hline $\mathrm{P} \div 4$ & 20 & $646 \%$ & 8 & $2 \div 2: 5$ & - & - & 1 & $\pm 0=$ & $\div$ & $121 \%$ & 33 \\
\hline IoraI & 91 & $639=$ & 3 & $61=$ & 2 & $1=2$ & 8 & $61:=$ & 23 & $17=$ & 132 \\
\hline
\end{tabular}

Sumber Data Primer, (Diolah)

\section{Keterangan}

Pdi atas1 :Tanggapan responden terhadap pernyataan bahwa penerima dana telah disertai bukti-bukti

Pdi atas2 : Tanggapan responden terhadap pernyataan bahwa bukti penerimaan dana telah dibukukan dengan tertib.

Pdi atas3 : Tanggapan responden terhadap pernyataan bahwa pengeluaran dana partai politik telah disertai bukti pengeluaran.

Pdi atas4 : Tanggapan responden terhadap pernyataan bahwa bukti pengeluaran dana partai politik dibukukan dengan tertib.

Tabel di atas menunjukkan tanggapan responden terhadap penggunaan keuangan partai politik dari segi bukti transaksi. Sebagai ilustrasi tanggapan responden terhadap pernyataan bahwa penerima dana telah disertai bukti-bukti yaitu 25 (75,8\%) responden menyatakan sangat tidak setuju, $3(9,1 \%)$ responden menyatakan setuju, dan $5(15,2 \%)$ responden menyatakan setuju.

\section{Alokasi}

Tabel a

Persepai Mrengenai Aloloasi

\begin{tabular}{|c|c|c|c|c|c|c|c|c|c|c|c|}
\hline \multirow{2}{*}{ Peruyatan } & \multicolumn{2}{|c|}{ STS } & \multicolumn{2}{|c|}{75} & \multicolumn{2}{|c|}{$\mathbf{N}$} & \multicolumn{2}{|r|}{5} & \multicolumn{2}{|r|}{35} & \multirow{2}{*}{ Total } \\
\hline & $\mathrm{N}$ & 20 & $\mathrm{~N}$ & 06 & $\mathrm{~N}$ & $\mathrm{Ab}$ & $\mathbf{F}$ & 06 & $\mathrm{M}$ & 96 & \\
\hline P51 & 27 & $3183=$ & - & - & - & - & $\Xi$ & $152 \%$ & 1 & $30 \%$ & 33 \\
\hline$P 5=1$ & 23 & $69-9=$ & - & - & + & - & 6 & 1823 & 4 & $121=$ & 33 \\
\hline Tot:I & 50 & $50 y=$ & + & - & + & - & 11 & $167=$ & 5 & $76^{0}=$ & 56 \\
\hline
\end{tabular}

Sumber Data Primer.

\section{Keterangan}

P5.1:Tanggapan responden terhadap pernyataan bahwa bantuan keuangan telah dialokasikan dengan benar

P5.2:Tanggapan responden terhadap pernyataan bahwa bantuan keuangan telah dialokasikan sesuai dengan porsi. 
Tabel di atas menunjukkan tanggapan responden terhadap terhadap penggunaan keuangan partai politik dari segi alokasi. Sebagai ilustrasi tanggapan responden terhadap pernyataan bahwa bantuan keuangan telah dialokasikan dengan benar yaitu 27 (81,8\%) responden menyatakan sangat tidak setuju, $5(15,2 \%)$ responden menyatakan setuju, dan 1 $(3 \%)$ responden menyatakan setuju.

\section{Efisiensi}

Tabel 9

Persepi inengenai Eticiensi

\begin{tabular}{|c|c|c|c|c|c|c|c|c|c|c|c|}
\hline \multirow{2}{*}{ Permy a tesn } & \multicolumn{2}{|c|}{$5 T S$} & \multicolumn{2}{|c|}{ IS } & \multicolumn{2}{|r|}{$\mathrm{N}$} & \multicolumn{2}{|c|}{5} & \multicolumn{2}{|c|}{55} & \multirow{2}{*}{ Zots] } \\
\hline & $\mathbf{x}$ & $4 s$ & $\mathrm{~N}$ & 6 & $\boldsymbol{N}$ & 86 & $\boldsymbol{N}$ & 60 & $\mathrm{~N}$ & 20 & \\
\hline P61 & 19 & 5769 & I & $30^{\circ}=$ & $\div$ & $121^{1}=$ & 7 & 2113 & 2 & $61^{\circ}=$ & 33 \\
\hline 202 & 25 & $758=$ & - & - & 1. & $30 \%$ & \pm & $1213=$ & 3 & $9.1 \%$ & 3 \\
\hline Tatal & \pm \pm & $657=$ & 1 & 158 & 5 & $76=$ & 11 & $166^{\circ}=$ & \pm & -5 & 65 \\
\hline
\end{tabular}

Sumber Dats Primer. (Diolah)

\section{Keterangan}

P6.1:Tanggapan responden terhadap pernyataan bahwa dana partai politik telah digunakan secara optimal

P6.2: Tanggapan responden terhadap pernyataan bahwa dana partai politik telah digunakan sesuai tujuan yang ingin dicapai partai politik dengan menggunakan sumberdaya yang optimal.

Tabel di atas menunjukkan tanggapan responden terhadap penggunaan keuangan partai politik dari segi efisiensi. Sebagai ilustrasi tanggapan responden terhadap pernyataan bahwa dana partai politik telah digunakan secara optimal yaitu 19 (57,6\%) responden menyatakan sangat tidak setuju, 1 (3\%) responden menyatakan tidak setuju, $4(12,1 \%)$ responden menyatakan netral, $7(21,2 \%)$ responden menyatakan setuju, dan $2(6,1 \%)$ responden menyatakan setuju.

\section{Pertanggungjawaban Keuangan Partai Politik.}

Persepsi akuntan publik terhadap akuntabilitas keuangan partai politik di tinjau dari segi pertanggungjawaban keuangan partai politik yang terdiri dari aspek pencatatan dan pelaporan.

\section{Pencatatan}


Tabel 10

\begin{tabular}{|c|c|c|c|c|c|c|c|c|c|c|c|}
\hline \multirow{2}{*}{ pernyatam } & \multicolumn{2}{|c|}{ STS } & \multicolumn{2}{|c|}{ TS } & \multicolumn{2}{|c|}{$\mathbf{N}$} & \multicolumn{2}{|r|}{5} & \multicolumn{2}{|c|}{$5 S$} & \multirow{2}{*}{ Total } \\
\hline & $\mathbf{N}$ & 90 & $\mathrm{~N}$ & 80 & $\mathrm{~N}$ & 90 & $\mathbf{N}$ & 90 & $\mathrm{~N}$ & 90 & \\
\hline$p=1$ & 22 & $6679=$ & - & - & 2. & $6.1^{\circ}=$ & - & - & 9 & $273 \%=$ & 33 \\
\hline$p ? 2$ & 18 & $545^{2} \%$ & 9 & $2732=$ & 1 & $3.0 \%$ & 4 & $121^{2} \mathrm{x}$ & 1 & $3.0 \%=$ & 33 \\
\hline D73 & 15 & $455 \%$ & 5 & $152^{\circ}=$ & - & - & $g$ & $273 \%$ & 4 & $121^{a}=$ & 33 \\
\hline 274 & 20 & $60.6 \%=$ & - & - & - & - & 7 & $212 \%=$ & 6 & $182=$ & 33 \\
\hline P75 & 21 & $63.5 \%$ & 1 & $30 \%=$ & - & - & 5 & $152 \%$ & 6 & $182=$ & 33 \\
\hline$p 76$ & 23 & $697 \%$ & - & $=$ & - & - & 6 & $182 \%$ & 4 & $121 \%$ & 33 \\
\hline Iotal & 119 & $601^{2}=$ & 15 & $-6^{0}=$ & 3 & $16^{2}=$ & 31 & $156^{2}=$ & 301 & $152^{\circ}=$ & 198 \\
\hline
\end{tabular}

Keterangan

P7.1: Tanggapan responden terhadap pernyataan bahwa pengurus partai politik telah melakukan pencatatan atas semua penerimaan partai

P7.2 :Tanggapan responden terhadap pernyataan bahwa pengurus partai politik telah melakukan pembukuan.

P7.3 : Tanggapan responden terhadap pernyataan bahwa pengurus partai politik telah memelihara daftar penerimaan secara tertib.

P7.4 :Tanggapan responden terhadap pernyataan bahwa pengurus partai politik telah melakukan pencatatan atas semua pengeluaran partai politik.

P7.5 : Tanggapan responden terhadap pernyataan bahwa pengurus partai politik telah melakukan pembukuan

P7.6 :Tanggapan responden terhadap pernyataan bahwa dana pengurus partai politik telah memelihara daftar penerimaan secara tertib

Tabel di atas menunjukkan tanggapan responden terhadap pertanggungjawaban keuangan partai politik dari segi pencatatan. Sebagai ilustrasi tanggapan responden terhadap pernyataan bahwa pengurus partai politik telah melakukan pencatatan atas semua penerimaan partai yaitu $22(66,7 \%)$ responden menyatakan sangat tidak setuju, $2(6,1 \%)$ responden menyatakan netral, $9(27,3 \%)$ responden menyatakan sangat setuju.

\section{Pelaporan}


Tabel 11

Pertepsi Mrengenai Felaporan

\begin{tabular}{|c|c|c|c|c|c|c|c|c|c|c|c|}
\hline \multirow{2}{*}{ PerHygtan } & \multicolumn{2}{|c|}{$5 \pi 5$} & \multicolumn{2}{|r|}{ Is } & \multicolumn{2}{|r|}{$\mathrm{N}$} & \multicolumn{2}{|r|}{5} & \multicolumn{2}{|r|}{$\mathrm{SS}$} & \multirow{2}{*}{ Iatal } \\
\hline & $\mathbf{w}$ & 86 & $\mathbf{N}$ & 96 & $\mathbf{N}$ & 80 & $\mathrm{~N}$ & 96 & $\mathbf{N}$ & 00 & \\
\hline I9 I & $2 \div$ & $72-9=$ & 3 & $919=$ & - & - & $\Xi$ & $919=$ & 3 & $91^{3}=$ & 33 \\
\hline 992 & 13 & $39 \div 3$ & $\div$ & $1219=$ & 4 & $121:=$ & 5 & $152=$ & 7 & $212=$ & 35 \\
\hline I9 & 21 & $5369=$ & $\div$ & $1219=$ & 2 & $61^{9}=$ & 2 & $61 \%$ & 4 & $1219=$ & 55 \\
\hline $\mathrm{PB} 4$ & 12 & $30 \div 9=$ & 7 & $212=$ & $E$ & $1 \equiv 2=$ & 6 & $18=$ & 3 & $91^{1}=$ & 33 \\
\hline PQ & 16 & $485=$ & 17 & 3599 & 1 & $30=$ & 2 & $51=$ & 3 & $91^{2}=$ & 35 \\
\hline I8 5 & 14 & $+2 \div 9=$ & 7 & 21213 & 3 & $91=$ & 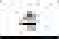 & $121=$ & 5 & $152 \%$ & 33 \\
\hline $\mathrm{PB} 7$ & 23 & $69-7=$ & - & - & - & - & $E$ & $152=$ & 5 & $152=$ & 53 \\
\hline PB & 15 & $455^{\prime}=$ & 7 & $2123=$ & - & - & 7 & $112=$ & 4 & $111^{\prime}=$ & 35 \\
\hline P89 & 25 & $69-9=$ & 1 & $30=$ & - & - & 6 & $182=$ & 3 & $91:=$ & 33 \\
\hline I810 & 21 & $636=$ & 4 & $121^{\prime}=$ & 2 & $61=$ & 2 & $61=$ & 4 & $121=$ & 53 \\
\hline Iat:1 & 185 & $36069=$ & 50 & $1 \pm 1 \leq=$ & 15 & $\pm 5 \leq 0$ & $\div 3$ & 1262 & 37 & $11=1:=$ & 330 \\
\hline
\end{tabular}

P8.1: Tanggapan responden terhadap pernyataan bahwa Pengurus partai politik telah menyusun laporan penerimaan keuangan kepada anggota partai politik.

P8.2: Tanggapan responden terhadap pernyataan bahwa pengurus partai politik telah menyusun laporan penerimaan kauangan kepada donatur.

P8.3 :Tanggapan responden terhadap pernyataan bahwa pengurus partai politik telah menyusun laporan penerimaan keuangan kepada supplier.

P8.4: Tanggapan responden terhadap pernyataan bahwa pengurus partai politik telah menyusun laporan penerimaan keuangan kepada konstituen.

P8.5 : Tanggapan responden terhadap pernyataan bahwa pengurus partai politik telah menyusun laporan pengeluaran keuangan kepada anggota partai politik.

P8.6 :Tanggapan responden terhadap pernyataan bahwa pengurus partai politik telah menyusun laporan pengeluaran kauangan kepada donatur.

P8.7: Tanggapan responden terhadap pernyataan bahwa pengurus partai politik telah menyusun laporan pengeluaran keuangan kepada supplier.

P8.8: Tanggapan responden terhadap pernyataan bahwa pengurus partai politik telah menyusun laporan pengeluaran keuangan kepada konstituen.

P8.9:Tanggapan responden terhadap pernyataan bahwa pengurus partai politik telah menyampaikan laporan pertanggungjawaban penerimaan keuangan bersumber dari APBD secara berkala 1 tahun sekali kepada pemerintah.

P8.10:Tanggapan responden terhadap pernyataan bahwa pengurus partai politiktelah menyampaikan laporan pertanggungjawaban pengeluaran keuangan bersumber dari APBD secara berkala 1 tahun sekali kepada pemerintah.

Tabel di atas menunjukkan tanggapan responden terhadap pertanggungjawaban keuangan partai politik dari segi pelaporan. Sebagai ilustrasi tanggapan responden terhadap pernyataan bahwa pengurus partai politik telah menyusun laporan penerimaan keuagan kepada anggota partai politik yaitu $24(72,7 \%)$ responden menyatakan sangat tidak setuju, 3 
$(9,1 \%)$ responden menyatakantidak setuju, $3(9,1 \%)$ responden menyatakan setuju, dan 3 responden menyatakan sangat setuju.

\section{Dana Kampanye}

\begin{tabular}{|c|c|c|c|c|c|c|c|c|c|c|c|}
\hline \multirow{2}{*}{ Pernyatasin } & \multicolumn{2}{|c|}{ SIS } & \multicolumn{2}{|c|}{ TS } & \multicolumn{2}{|r|}{$\mathrm{N}$} & \multicolumn{2}{|c|}{5} & \multicolumn{2}{|r|}{55} & \multirow{2}{*}{ Tot:1 } \\
\hline & $N$ & 50 & $\mathrm{~N}$ & 96 & $\mathbf{N}$ & 86 & $\mathrm{~N}$ & 96 & $\mathbf{N}$ & 80 & \\
\hline$I 91$ & 8 & $2+2 \mathrm{a}$ & 3 & $21 \%$ & 3 & $91 \%$ & 9 & $275=$ & 10 & $303 \%$ & 33 \\
\hline IS2 & 9 & $273=$ & - & - & 4 & $121^{2}=$ & B & $2+28$ & 12 & $35+9=$ & 33 \\
\hline$I 93$ & 9 & 2738 & 2 & $61^{9}=$ & 1 & 309 & $\Xi$ & $182 \%$ & 16 & 4953 & 33 \\
\hline IDI & 12 & $36 \div 2=$ & 1 & 309 & - & - & 8 & $2+28=$ & 12 & $36-2$ & 33 \\
\hline PS5 & 7 & $211^{3}=$ & 6 & $182=$ & - & - & 7 & $212 \%$ & 13 & $39 \div 2$ & 35 \\
\hline$P=6$ & 6 & $182=$ & 6 & 182 & - & - & 9 & $2-5=$ & 12 & $354^{\circ}=$ & 33 \\
\hline 99 & 8 & $2+20$ & $\div$ & $121 \%=$ & - & - & 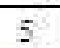 & $152 \%$ & 16 & $485^{\circ}=$ & 53 \\
\hline$F 98$ & 8 & $2+23=$ & 4 & $121 \%$ & - & - & 18 & $5+5 \%=$ & 3 & $91^{2}=$ & 35 \\
\hline Iotal & 57 & $255 \%$ & 26 & 933 & 3 & 313 & 69 & $261^{\circ}$ & $9=$ & $355 \%$ & $26 \div$ \\
\hline
\end{tabular}

P9.1 : Tanggapan responden terhadap pernyataan bahwa partai politik telah membuat laporan dana kampanye

P9.2 :Tanggapan responden terhadap pernyataan bahwa partai politik telah memiliki rekening khusus dana kampanye.

P9.3: Tanggapan responden terhadap pernyataan bahwa Rekening khusus dana kampanye partai politik telah didaftarkan ke komisi pemilihan umum.

P9.4: Tanggapan responden terhadap pernyataan bahwa Laporan pembukaan rekening khusus dana kampanye partai politik telah menjelaskan sumberperolehan saldo awal.

P9.5 :Tanggapan responden terhadap pernyataan bahwa Laporan pembukaan rekening khusus dana kampanye partai politik telah menjelaskan rincian perhitungan penerimaan yang telah dilakukan sebelumnya.

P9.6 :Tanggapan responden terhadap pernyataan bahwa Laporan pembukaanrekening khusus dana kampanye partai politik telah menjelaskan rincian perhitungan pengeluaran yang telah dilakukan sebelumnya.

P9.7 :Tanggapan responden terhadap pernyataan bahwa Laporan dana kampanyetelah diserahkan kepada KAP.

P9.8 :Tanggapan responden terhadap pernyataan bahwa Laporan dana kampanye telah diserahkan kepada KAP maksimal 60 hari setelah pemungutan suara.

Tabel di atas menunjukkan tanggapan responden terhadap akuntabilitas dana kampanye. Sebagai ilustrasi tanggapan responden terhadap pernyataan bahwa partai politik telah membuat laporan dana kampanye yaitu $8(24,2 \%)$ responden menyatakan sangat tidak setuju, $3(9,1 \%)$ responden menyatakantidak setuju, $3(9,1 \%)$ responden menyatakan netral, 
$9(27,3) \%$ responden menyatakan setuju, dan $10(30,3 \%)$ responden menyatakan sangat setuju.

\section{Pengujian Instrumen Penelitian}

\section{Uji Validitas dan Uji Reliabilitas}

Hasil pengujian validitas dan reliabilitas dinyatakan semua instrumen penelitian yang akan digunakan sudah valid dan relliabel.

\section{Pengujian Hipotesis}

Tujuan dari pengujian ini adalah untuk menguji perbedaan mean data hasil kenyataan dilapangan dengan data standart atau ketentuan buku atau peraturan atau data hasil kenyataan di lapangan yang dianggap sebagai standart dengan syarat jika probabilitas > 0,05 maka $\mathrm{H}_{0}$ diterima, jika probabilitas $<0,05$ maka $\mathrm{H}_{0}$ di tolak.

\section{Pengujian Hipotesis Pertama $\left(H_{1}\right)$}

H1 : Diduga tidak terdapat perbedaan persepsi akuntan publik terhadap akuntabilitas keuangan Partai Politik.

C.nmhar 1

Cune-jample test

\begin{tabular}{|c|c|c|c|c|c|c|}
\hline & \multicolumn{6}{|c|}{ iest value - 0} \\
\hline & \multirow[b]{2}{*}{$t$} & \multirow[b]{2}{*}{.91} & \multirow{2}{*}{ 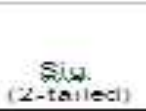 } & \multirow{2}{*}{$\begin{array}{c}\text { Meati } \\
\text { Litterence }\end{array}$} & \multicolumn{2}{|c|}{$\begin{array}{l}96 \% \text { Cutificletue } \\
\text { Interval ot the } \\
\text { Difreterive }\end{array}$} \\
\hline & & & & & Lower & Upper \\
\hline 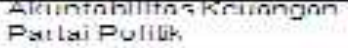 & 17.107 & 32 & .000 & 88.12 & 77.80 & 88.86 \\
\hline
\end{tabular}

Sumber Data Frimer .(Diolah)

Gambar di atas uji hipotesis menunjukkan bahwa nilai sig.(2-tailed) $<0,05$, maka $\mathrm{H}_{0}$ ditolak dan $\mathrm{H}_{1}$ diterima. Hal ini menunjukkan bahwa tidak terdapat perbedaan persepsi akuntan publik terhadap akuntabilitas keuangan partai politik. Sedangkan untuk hasil pengujian hipotesis terhadap masing-masing variabel dapat dilihat pada tabel berikut:

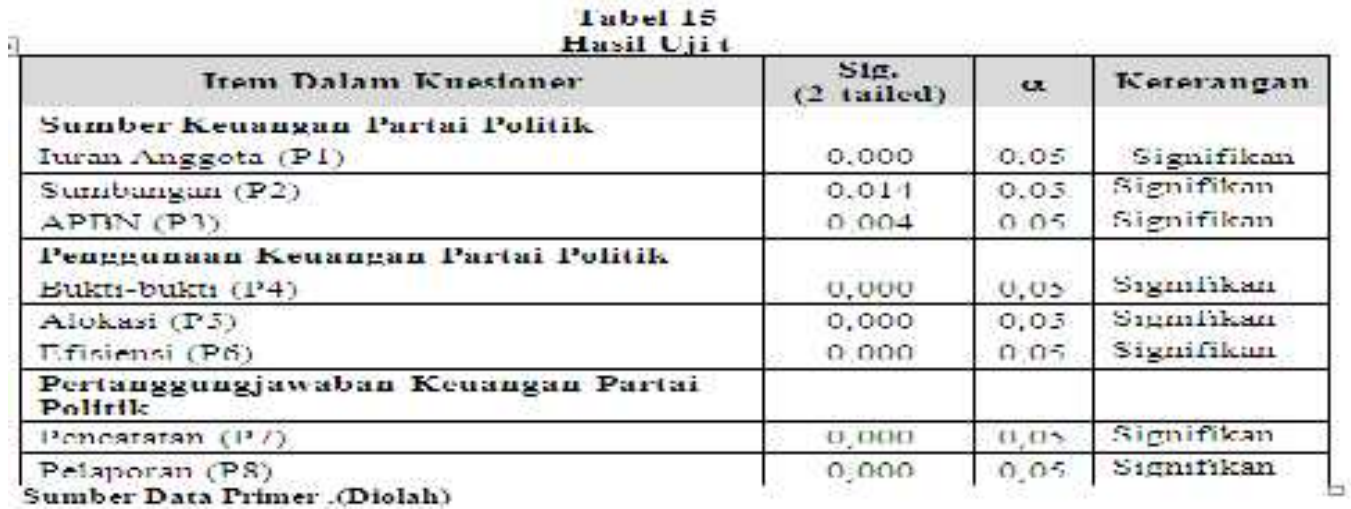

Tabel di atas menunjukkan bahwa seluruh variable memiliki nilai sig. $(2$-tailed) $<0,05$ 
maka $\mathrm{H}_{1}$ diterima. Hasil pengujian selengkapnya dapat dilihat pada lampiran 32.

\section{Sumber Keuangan Partai Politik luran Anggota}

Tabel 15 menunjukkan bahwa variable iuran anggota memiliki nilai sig. (2-tailed) $<0,05$, yaitu 0,000 . Hal ini menunjukkan bahwa $H_{0}$ ditolak dan $H_{1}$ diterima yang berarti tidak terdapat perbedaan persepsi akuntan publik terhadap akuntabilitas keuangan partai politik dari segi iuran anggota.

\section{Sumbangan}

Tabel 15 menunjukkan bahwa variable sumbangan memiliki nilai sig.(2-tailed) $<0,05$, yaitu 0,014 . Hal ini menunjukkan bahwa $\mathrm{H}_{0}$ ditolak dan $\mathrm{H}_{1}$ diterima yang berarti tidak terdapat perbedaan persepsi akuntan publik terhadap akuntabilitas keuangan partai politik dari segi sumbangan.

\section{APBN}

Tabel 15 menunjukkan bahwa variable APBN memiliki nilai sig.(2-tailed)<0,05, yaitu 0,004 . Hal ini menunjukkan bahwa $\mathrm{H}_{0}$ ditolak dan $\mathrm{H}_{1}$ diterima yang berarti tidak terdapat perbedaan persepsi akuntan publik terhadap akuntabilitas keuangan partai politik dari segi APBN.

\section{Penggunaan Keuangan Partai Politik Bukti-bukti}

Tabel 15 menunjukkan bahwa variable bukti - bukti memiliki nilai sig.(2-tailed)<0,05, yaitu 0,000 . Hal ini menunjukkan bahwa $H_{0}$ ditolak dan $H_{1}$ diterima yang berarti tidak terdapat perbedaan persepsi akuntan publik terhadap akuntabilitas keuangan partai politik dari segi bukti-bukti.

\section{Alokasi}

Tabel 15 menunjukkan bahwa variable alokasi memiliki nilai sig.(2-tailed) $<0,05$, yaitu 0,000. Hal ini menunjukkan bahwa $\mathrm{H}_{0}$ ditolak dan $\mathrm{H}_{1}$ diterima yang berarti tidak terdapat perbedaan persepsi akuntan publik terhadap akuntabilitas keuangan partai politik dari segi alokasi.

\section{Efisiensi}

Tabel 15 menunjukkan bahwa variable efisiensi memiliki nilai sig.(2-tailed)<0,05, yaitu 0,000. Hal ini menunjukkan bahwa $\mathrm{H}_{0}$ ditolak dan $\mathrm{H}_{1}$ diterima yang berarti tidak terdapat perbedaan persepsi akuntan publik terhadap akuntabilitas keuangan partai politik dari segi efisiensi.

\section{Pertanggungjawaban Keuangan Partai Politik \\ Pencatatan}


Tabel 15 menunjukkan bahwa variable pencatatan memiliki nilai sig. $(2$-tailed) $<0,05$, yaitu 0,000. Hal ini menunjukkan bahwa $\mathrm{H}_{0}$ ditolak dan $\mathrm{H}_{1}$ diterima yang berarti tidak terdapat perbedaan persepsi akuntan publik terhadap akuntabilitas keuangan partai politik dari segi pencatatan.

\section{Pelaporan}

Tabel 15 menunjukkan bahwa variable pelaporan memiliki nilai sig. (2-tailed)<0,05, yaitu 0,000 . Hal ini menunjukkan bahwa $H_{0}$ ditolak dan $H_{1}$ diterima yang berarti tidak terdapat perbedaan persepsi akuntan publik terhadap akuntabilitas keuangan partai politik dari segi pelaporan.

\section{Pengujian Hipotesis Kedua (H2)}

$\mathrm{H}_{2}$ : Diduga tidak terdapat perbedaan persepsi akuntan publik terhadap akuntabilitas dana kampanye.

\section{Gambar 2}

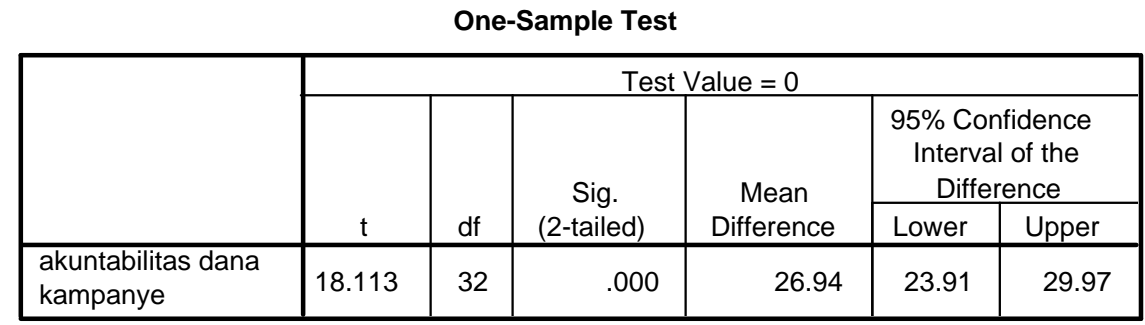

Sumber : Data Primer.(Diolah)

Gambar 2 uji hipotesis menunjukkan bahwa nilai sig.(2-tailed) $<0,05$, maka $\mathrm{H}_{0}$ ditolak dan $\mathrm{H}_{1}$ diterima. Hal ini menunjukkan bahwa tidak terdapat perbedaan persepsi akuntan publik terhadap akuntabilitas laporan dana kampanye.

\section{Analisis Hasil Penelitian}

Sebagaimana telah disebutkan dalam bagian sebelumnya, bahwa penelitian ini dilaksanakan terhadap Kantor Akuntan Publik yang berada di kota Malang dan pernah melakukan audit terhadap laporan keuangan partai politik yang berjumlah sebanyak 6 Kantor Akuntan Publik.

\section{Akuntabilitas Keuangan Partai Politik}


Akuntabilitas keuangan partai politik terdiri dari tiga poin penting. Poin pertama yaitu sumber keuangan partai politik yang terdiri dari iuran anggota, sumbangan, dan bantuan dari Anggaran Pendapatan Belanja Negara/Daerah. Poin kedua adalah mengenai penggunaan keuangan partai politik yang terdiri dari bukti-bukti, alokasi, dan efisiensi. Sedangkan poin ketiga adalah mengenai pertanggungjawaban keuangan partai politik yang terdiri dari pencatatannya dan pelaporannya.

\section{Sumber Keuangan Partai Politik}

Hasil pengujian terhadap frekuensi jawaban responden menunjukkan bahwa tanggapan responden terhadap sumber keuangan partai politik yang berasal dari iuran anggota, sumbangan, dan bantuan dari Anggaran Belanja dan Pendapatan Negara (APBN) mayoritas menyatakan sangat tidak setuju. Hal ini bertolak belakang dengan hasil penelitian yang dilakukan oleh Ismi yang hasilnya menyebutkan bahwa laporan sumber keuangan partai politik yang berasal dari iuran anggota, sumbangan, dan bantuan dari Anggaran Belanja dan Pendapatan Negara (APBN) dinyatakan sudah akuntabel dan dapat dipertanggungjawabkan.

\section{Penggunaan Keuangan Partai Politik}

Hasil pengujian terhadap frekuensi jawaban responden menunjukkan bahwa tanggapan responden terhadap penggunaan keuangan partai politik yang terdiri dari buktibukti transaksi, alokasi, dan efisiensi mayoritas menyatakan sangat tidak setuju. Hal ini bertolak belakang dengan hasil penelitian yang dilakukan oleh Ismi yang hasilnya menyebutkan bahwa laporan penggunaan keuangan partai politik yang terdiri dari bukti-bukti transaksi, alokasi, dan efisiensi dinyatakan sudah akuntabel dan dapat dipertanggungjawabkan.

\section{Pertanggungjawaban Keuangan Partai Politik}

Hasil pengujian terhadap frekuensi jawaban responden menunjukkan bahwa tanggapan responden terhadap pertanggungjawaban keuangan partai politik yang terdiri dari pencatatan dan pelaporan mayoritas menyatakan sangat tidak setuju. Hal ini bertolak belakang dengan hasil penelitian yang dilakukan oleh Ismi yang hasilnya menyebutkan bahwa laporan pertanggungjawaban keuangan partai politik yang terdiri dari pencatatan dan pelaporan dinyatakan sudah akuntabel dan dapat dipertanggungjawabkan.

\section{Akuntabilitas Dana Kampanye}

Hasil pengujian terhadap frekuensi jawaban responden menunjukkan bahwa tanggapan responden terhadap pertanggungjawaban keuangan partai politik yang terdiri dari 
pencatatan dan pelaporan mayoritas menyatakan sangat setuju. Hal ini bertolak belakang dengan hasil penelitian yang dilakukan oleh Ismi yang hasilnya menyebutkan bahwa laporan pertanggungjawaban keuangan partai politik yang terdiri dari pencatatan dan pelaporan dinyatakan tidak akuntabel dan tidak dapat dipertanggungjawabkan.

Pengujian validitas menunjukkan hasil bahwa seluruh skala pengukuran dalam penelitian dinyatakan valid untuk digunakan sebagai instrument dalam penelitian. Selanjutnya hasil dari pengujian reliabilitas untuk smua skala pengukuran dalam penelitian ini juga menunjukkan reliabel atau dapat dipercaya dan konsisten. Untuk menjawab hipotesis peneliti menggunakan uji one sample $t$ tes. Hasil pengujian hipotesis pertama menunjukkan bahwa hipotesis peneliti di terima yang berarti tidak terdapat perbedaan persepsi akuntan publik terhadap akuntabilitas keuangan partai politik. Sedangkan hasil pengujian hipotesis kedua juga menunjukkan bahwa hipotesis peneliti di terima yang berarti tidak terdapat perbedaan persepsi akuntan publik terhadap akuntabilitas dana kampanye.

\section{PENUTUP}

Penelitian ini bertujuan untuk mengetahui persepsi akuntan publik terhadap akuntabilitas keuangan partai politik. Berdasarkan hasil pengujian dengan menggunakan uji t, maka hasil penelitian ini dapat disimpulkan: (a) Tidak terdapat perbedaan persepsi akuntan publik terhadap akuntabilitas keuangan partai politik, (b) Tidak terdapat perbedaan persepsi akuntan publik terhadap akuntabilitas dana kampanye. Saran untuk penelitian yang akan datang adalah: (a) untuk meningkatkan hasil penelitian lebih akurat, maka perlu dilakukan penelitian ulang diwaktu mendatang dengan penyebaran kuisioner langsung pada akuntan publik dan ditindak lanjuti dengan wawancara dengan pihak yang diteliti, (2) Untuk penelitian selanjutunya diharapkan tidak hanya di Kantor Akuntan Publik di wilayah kota Malang, tetapi diperluas pada Kantor Akuntan Publik diluar wilayah Malang.

\section{Daftar Pustaka}

Arens \& Loebecke .2003. Auditing. Pendekatan Terpadu Adaptasi oleh Amir Abadi Jusuf. Buku satu Salemba Empat. Jakarta

Bastian.Indra 2007.Akuntansi Untuk LSM dan Partai Politik. Airlangga. Jakarta

Halim, Abdul.2002.Pokok-Pokok Materi Statistik Jilid 1. Bumi Aksara. Jakarta

Halim, Abdul.2002.Pokok-Pokok Materi Statistik Jilid 1. Bumi Aksara. Jakarta

Ikatan Akuntan Indonesia.2007.Pernyataan Standart Akuntansi Keuangan No.45 Pelaporan Keuangan Organisasi Nirlaba. Jakarta.Ikatan Akuntan Indonesia, Salemba Empat.

Komisi Pemilihan Umum. 2003. Keputusan KPU nomor 676 Tahun 2003 tentang Tata Administrasi Keuangan Dan Sistem Akuntansi Keuangan Partai Politik, Serta Pelaporan Dana Kampanye Peserta Pemilihan Umum. 
Kencana, Inu.1997.IImu Politik. Rineka Cipta. Jakarta.

Kotler,Philips.2005.manajemen Pemasaran Ed.11 Jilid I. Indeks. Jakarta.

Kotler,Philips.2005.manajemen Pemasaran Ed.11 Jilid I. Indeks. Jakarta.

Rahman,Agus. 2007. Partai Politik di Indonesia.Ghalia Indonesia.Jakarta.

Rangkuti,Freddy.2003.Riset Pemasaran. Gramedia Pustaka Utama.Jakarta.

Sunarto. 2003.Auditing.Panduan.Yogyakarta.

Umum,Ihyaul.2004.Peranan IAI Dalam Mewujudkan Good Governance (Sebuah Kajian atas Tuntutan Profesionalisme Akuntan Dalam Pelaksanaan Audit Laporan Keuangan Partai Politik.) penelitian Bidang IImu, dibiayai DPP UMM 